\title{
The History of Academic Freedom in Africa: Issues, Challenges and Perspectives
}

\author{
Leonidas Ndereyimana \\ Institute of Graduate Studies and Research, Faculty of Business Administration, European University of Lefke, Lefke, Cyprus \\ Email: babonny2006@yahoo.fr
}

How to cite this paper: Ndereyimana, L. (2021). The History of Academic Freedom in Africa: Issues, Challenges and Perspectives. Advances in Literary Study, 9, 154-158. https://doi.org/10.4236/als.2021.93017

Received: May 20, 2021

Accepted: July 17, 2021

Published: July 20, 2021

Copyright $\odot 2021$ by author(s) and Scientific Research Publishing Inc. This work is licensed under the Creative Commons Attribution International License (CC BY 4.0).

http://creativecommons.org/licenses/by/4.0/

\begin{abstract}
This work examines the history of academic freedom in the world with particular emphasis on academic freedom in Africa and its perspectives. This work harbors on the hypothetical contention that academic freedom is the cornerstone for a free society and liberal education. It further proves that academic freedom is an engine for sustainable democracy and prosperity. Written against the backdrop of historical approach, this work concludes that freedom of teaching, research and publication have been defended for many centuries. Because of this many earlier academic freedom defenders were harassed for many years but their cause persists to date.
\end{abstract}

\section{Keywords}

Academic, Freedom, Liberal, Education, Africa

\section{Introduction}

The online dictionary Wikipedia defines academic freedom as the belief that academic enquiry by faculty members is essential to the mission of the academy as well as the principles of academia and that scholars should have freedom to teach or communicate ideas or facts without being targeted for oppression, job loss or imprisonment (Wikipedia). In the Encyclopedia of Ethics, Georges Smithson and Janice Moulton (2002) define academic freedom as the freedom to teach and to do research in any area without constraint to discover and promulgate new ideas no matter how controversial. Like other accepted freedoms, academic freedom requires individuals, authorities and governments not to allow scholars to work without restraint but also to prevent any interference with this freedom. In addition, academic freedom seems to require something more: that society provides conditions in which new ideas can be generated, nurtured and 
freely exchanged. Besides, the Association of American Colleges and Universities simply defines academic freedom as liberal education whereas the Legal Definition of Academic Freedom anchors that it is the right to teach as one sees it fits, but not necessarily the right to teach evil. These four definitions converge and motivate us to help the reader know the historical origins of academic freedom.

\section{The Historical Origins of Academic Freedom Worldwide}

Academic freedom has long historical origins. Georges Robinson and Janice Moulton (2002) mention that historical examples show the need for academic freedom. Socrates (c. 470-399 B.C) was put to death for corrupting the youth of Athens with his ideas. Galileo (1564-1642) was sentenced to life imprisonment for advocating the Copernican view of the solar system. Descartes (1596-1650) suppressed his own writing to avoid similar trouble. Teachers were fired for telling their students about Darwin's (18-9-1882) views. The ideas of these great thinkers have survived, but we will never know how many others were completely suppressed.

The origins of academic freedom in the United States have strong foundations. In A Guide to Academic Freedom, Frederick P. Shaffer General Counsel and Senior Vice Chancellor for Legal Affairs, the City University of New York, stipulates that "the principles of academic freedom in the United States were heavily influenced by the thinking and practice at German universities and the growth of nonsectarian American universities in the second half of the nineteenth century. With the rise of ideological conflicts, especially relating to economic theory, faculty began to feel the need for protection against trustees and administrators who sought the dismissal of faculty whose views they found unpalatable". He anchors by stating that "In response to these conflicts, in 1915 the American Association of University Professors was founded and issued its Declaration on Principles of Academic Freedom and Academic Tenure". In accordance with this declaration, academic freedom has three components: freedom of inquiry and research, freedom of teaching within the university or college and freedom of extramural utterance and action. Academic freedom is further derived in the American Constitution's First Amendment which guarantees the freedom of speech in the American society.

In France, academic freedom is also recognized. Professors at Public universities and researchers at public research laboratories are expected, as well as civil servants, to behave in neutral manner and to not favor any political or religious point of view during course of their duties. However, the academic freedom of university professors is a fundamental principal recognized by the law of the Republic, as defined by the Constitutional Council. Furthermore, statute law declares about further education that "teachers-researchers (university professors and assistant professors), researchers and teachers are fully independent and enjoy full freedom of speech in the course of their research and teaching activities provided, they respect following university traditions and the dispositions of this code, principles of tolerance and objectivity". 
Similarly, the German Constitution guarantees academic freedom. "Art and science, research and teaching are free. Freedom of teaching does not absolve from the loyalty of the constitution." (Art. 5, Para. 3). In a tradition reaching back the $19^{\text {th }}$ Century, jurisdiction has understood this right as one to teach, study and conduct research freely, although the last concept has sometimes taken as the cover term of the first two. German professors have the right to determine the content of their lectures and to publish the result of their research without prior approval. Finally, there is academic freedom which permits self-academic governance and grants the university self-control of its internal affairs.

Furthermore, academic freedom is grounded in the Philippine society. As a matter of fact the 1987 Constitution states that "Academic freedom shall be enjoyed in all institutions of higher education." Philippine jurisprudence and courts of law, including the Philippine Supreme Court tend to reflexively defer to the institutional autonomy of higher institutions learning in determining academic decisions with respect to the outcomes of individual cases filed in the courts regarding the abuse of Academic Freedom by professors, despite the individual merits or demerits of any cases.

By the way, speaking about academic freedom in The World University News published on 11 March 2021, Robert Queen et al (2021) say that "universities ranking must include academic freedom". They further opine that in some highly ranked universities, there is no academic freedom. They operate in environments where academic freedom is highly restricted, where professors and students risk sacking, expulsion or worse for discussing topics that are not in favor or for asking certain questions.

The four abovementioned countries illustrate the foundations of academic freedom in developed societies from different corners of the world that is America, Europe and Asia. In the following chapter we are going to have a look at the academic freedom situation in the youngest continent Africa with the youngest universities worldwide.

\section{Academic Freedom in Africa and Perspectives}

Academic freedom in Africa is still a new issue. Despite Kampala Declaration on Academic Freedom in November 1990, researches prove that only the Republic of South Africa has entered in the history of Academic freedom in Africa. In fact, Section 16 of the 1996 Constitution of South Africa offers specific protection to academic freedom. However, there have been a large number of scandals around the restriction of academic freedom at a number of universities with particular concern being expressed about the situation at the University of KwaZulu-Natal.

By the way academic freedom which is also called liberal education by the Association of American Colleges and Universities is the way to boost free education in African universities. According to the Association of American Colleges and Universities (2006), "In any education of quality, students encounter an 
abundance of intellectual diversity-new knowledge, new perspectives, competing ideas, an alternative claim of truth. This intellectual diversity is experienced by some students as exciting and challenging, while others are confused and overwhelmed by the complexity. Liberal education, the nation's signature educational tradition, helps students develop the skills of analysis and critical inquiry with particular emphasis on exploring and evaluating competing claims and different perspectives. With its emphasis on breadth of knowledge and sophisticated habits of mind, liberal education is the best and most powerful way to build students' capacities to form their own judgments about complex or controversial questions". The Association of American Universities and Colleges believes that all academics should enjoy this kind of education, regardless of their schools or intended career. This highlights the great significance of liberal education in the world.

Therefore academic freedom is not only about professors of colleges and universities or researchers but also university students who need to have broad knowledge of the world to empower their critical thinking and debate. It is this critical mind which promotes scientific research and argumentation from which arise academic knowledge.

\section{Conclusion}

As academic freedom is very fundamental for any young and progressive society like Africa, it should be universal to consolidate the freedom of expression in Africa. However academics should know to adjust to different communities to avoid potential frustrations due to cultural, ethnic or religious differences. Because of this, liberal education should be promoted in Africa to make African societies more intellectual and more open to the world changes. This will also be the key to sustainable democracy and prosperity across the African continent.

Future research about academic freedom should deal with other regions of the world to help people know different regional differences and particularities.

This work is the result of online contributions from people and organizations whose electronic researches and material about academic freedom have been accessible and helped much in the completion of this research paper. Therefore I feel deeply indebted to express my acknowledgements to a selected number of them. First and foremost my deep gratitude is given to anyone who helped in one way or another for the completion of this research. Particular acknowledgement is extended to Codesria which inspired me to carry out this research. Special thanks go to Mr. Frederick P. Shaffer, General Counsel and Senior Vice Chancellor for Legal Affairs, The City University of New York. His online book about academic freedom is very commendable. I should also give many thanks to the Association of American Colleges and Universities as well as the Association of American Professors whose websites were a great source of information for me.

\section{Conflicts of Interest}

The author declares no conflicts of interest regarding the publication of this paper. 


\section{References}

Association of American Colleges and Universities (2006). https://www.aacu.org/

Queen, R. et al. (2021). Why University Ranking Must Include Academic Freedom. London: World University News.

Smithson, G., \& Moulton, J. (2002). Encyclopedia of Ethics. https://en.wikipedia.org/wiki/Encyclopedia_of_Ethics

The Legal Definition of Academic Freedom. https://www.thefreedictionary.com/Academic\%20Freedom

Wikipedia. https://en.wikipedia.org/wiki/Academic_freedom 